\title{
Autocrine stimulation of IGF1 in estrogen- induced growth of endometrial carcinoma cells: involvement of the mitogen-activated protein kinase pathway followed by up-regulation of cyclin D1 and cyclin E
}

\author{
Hiroyasu Kashima, Tanri Shiozawa, Tsutomu Miyamoto, Akihisa Suzuki, \\ Junko Uchikawa, Miyuki Kurai and Ikuo Konishi
}

Department of Obstetrics and Gynecology, Shinshu University School of Medicine, 3-1-1 Asahi, Matsumoto 390-8621, Japan

(Correspondence should be addressed to T Shiozawa; Email: tanri@ hsp.md.shinshu-u.ac.jp)

\begin{abstract}
To examine estrogen-induced growth mechanisms of endometrial carcinoma, we investigated the estrogen-induced activation of the mitogen-activated protein kinase (MAPK) pathway and cell cycle regulators. Estradiol $\left(E_{2}\right)$ treatment at concentrations of $10^{-8} \mathrm{M}$ and $10^{-6} \mathrm{M}$ to estrogen receptor (ER)-positive endometrial carcinoma Ishikawa cells for $24 \mathrm{~h}$ resulted in increased cell proliferation by $20 \%$ and $28 \%$ respectively. The $E_{2}$-induced proliferation was associated with the activation of extracellular signal-regulated kinase (MAPK) $3 / 1$ and up-regulation of cyclin D1 and E, which were suppressed by the addition of an MAP2K inhibitor (U0126) or an ER antagonist (ICI 182 780). Then, our screening for estrogen-inducible growth factors identified that IGF1 was up-regulated remarkably by $E_{2}$. Immunoprecipitation using conditioned medium of Ishikawa cells after $E_{2}$ treatment confirmed the $E_{2}$-induced secretion of IGF1 protein. Treatment with recombinant IGF1 stimulated cell proliferation in a dose-dependent fashion, in association with MAPK3/1 phosphorylation and up-regulation of cyclin D1 and E. These IGF1-induced responses were suppressed by treatment with MAP2K inhibitor or anti-IGF1 receptor antibody. Immunohistochemical staining confirmed the expression of activated MAPK3/1 in normal proliferative phase endometria and endometrial carcinomas, indicating the involvement of this pathway in actively proliferating endometrial tissues in vivo. These findings suggest that $\mathrm{E}_{2}$-induced proliferation of endometrial carcinoma cells is mediated by the MAPK3/1 pathway via autocrine stimulation of IGF1.
\end{abstract}

Endocrine-Related Cancer (2009) 16 113-122

\section{Introduction}

Endometrial carcinoma is one of the carcinomas known to have a clear relationship between hormonal stimulation and growth regulation (Murphy 1994). Estrogen stimulates the proliferation of normal and malignant endometrial cells expressing estrogen receptors (ER; Strauss \& Coutifaris 1999), via various mechanisms including increased ER expression (Granziani et al. 2003), up-regulation of growth factors and/or their receptors (Hana \& Murphy 1994, Kleinman et al. 1995), and induction of proto-oncogene FOS (Singleton et al. 2003). However, the intracellular molecular machineries underlying the regulation of estrogen-induced cell proliferation are still not fully elucidated.

Cell proliferation is generally evoked by extracellular growth signals such as growth factors and cytokines. After the binding of growth factors to the respective receptors, the conserved RAS/RAF/MAP2K/mitogenactivated protein kinase (MAPK) pathway acts to relay growth stimuli from activated RAS proteins via MAPK kinase 3/1 (MAP2K1/2) to MAPK1/3 kinase or extracellular signal-regulated kinase (MAPK)3/1 (Kolch 2000, Peyssonnaux \& Eychene 2001). The MAPK3/1 proteins are serine/threonine kinases that are rapidly activated by phosphorylation and translocated to 
the nucleus, which appears to be necessary for cell proliferation (Pages et al. 1993). MAPK3/1 activation eventually induces the expression of cell cycle regulators such as cyclins, and cyclin-dependent kinases (CDKs), which have essential roles to propel cell cycle progression (Sherr 1995, Nurse 1997). We have previously reported the cyclical expression of cyclin and CDKs in normal cycling endometrial tissues (Shiozawa et al. 1996), as well as the overexpression of these molecules in endometrial carcinoma ( $\mathrm{Li}$ et al. 1996, Shih et al. 2003), suggesting the involvement of cell cycle regulators in the growth of normal endometrium and in the acquisition of aggressive growth potential of endometrial carcinoma. We also revealed the estrogen-induced transcriptional activation of cyclin D1 via the induction of JUN in normal endometrial cells (Shiozawa et al. 2004).

Nevertheless, the involvement of cyclins in estrogeninduced cell proliferation in ER-positive endometrial carcinoma cells has not been elucidated. The role of the MAPK pathway in estrogen-induced cell proliferation and cell cycle regulator activation also remains undetermined. Therefore, in this study, we investigated the involvement of the MAPK pathway and the activation of cell cycle regulators in estradiol $\left(\mathrm{E}_{2}\right)$-induced cell proliferation of endometrial carcinoma cells. Then, we screened candidates of growth factors that can be induced by estrogen. Since we identified the up-regulation of IGF1 by estrogen, we focused on the involvement of IGF1 as an autocrine factor in estrogen-dependent growth of endometrial carcinoma cells.

\section{Materials and methods}

\section{Cell culture}

An ER-positive endometrial carcinoma cell line, Ishikawa, was kindly provided by Dr Nishida at Kasumigaura Medical Center (Tsuchiura, Ibaragi, Japan). Cells were cultured in Dulbecco's modified Eagle's medium (DMEM) (Invitrogen) with 15\% FCS (Biological Industries, Haemek, Israel) and 1\% antibiotic-antimycotic solution (Invitrogen). Incubation was carried out at $37{ }^{\circ} \mathrm{C}$ under $5 \% \mathrm{CO}_{2}$ in air. An ER antagonist, ICI 182780 , and an MAP2K inhibitor, U0126, were purchased from Sigma. Anti-IGF1 receptor antibody (Ab-3), which can neutralize the cell surface receptor, was purchased from Oncogene Research Products (San Diego, CA, USA). Before the $\mathrm{E}_{2}$ or IGF1 stimulation experiments, Ishikawa cells were pretreated with rapamycin $(500 \mathrm{ng} / \mathrm{ml}$; Invitrogen) in serum-starved medium (FCS $0.1 \%$ ) for $24 \mathrm{~h}$ to synchronize them to the G1 phase of the cell cycle. Then the cells were cultured for $24 \mathrm{~h}$ without rapamycin in the same medium to wash out the effect of the agent. ICI $182780, \mathrm{U} 0126$, or anti-IGF1 receptor antibody was added $1 \mathrm{~h}$ before the addition of $\mathrm{E}_{2}$ or IGF1.

\section{Western blotting}

Phosphorylation of MAPK3/1 was examined, using a specific antibody that recognizes phosphorylated MAPK3/1 in Ishikawa cells treated with various reagents by western blotting. Cells were lysed in a lysis buffer: $50 \mathrm{mmol} / \mathrm{l}$ Tris$-\mathrm{HCl}$ (pH 8.0), $0.25 \mathrm{~mol} / \mathrm{l} \mathrm{NaCl}, 0.5 \%$ NP-40, $1 \mathrm{mmol} / \mathrm{l}$ phenylmethylsulphonyl fluoride (Sigma), $1 \mu \mathrm{g} / \mathrm{ml}$ aprotinin (Roche Diagnostics), $1 \mu \mathrm{g} / \mathrm{ml}$ leupeptin (Roche Diagnostics), and $20 \mu \mathrm{g} / \mathrm{ml}$ $\mathrm{N}$-p-Tosyl-L-phenylalanine chloromethyl ketone (TPCK) (Roche Diagnostics). The lysates were centrifuged at $13000 \mathrm{~g}$ for $20 \mathrm{~min}$ at $4{ }^{\circ} \mathrm{C}$ and the supernatants were stored at $-80{ }^{\circ} \mathrm{C}$. Extracts equivalent to $50 \mu \mathrm{g}$ total protein were separated by SDS-PAGE (7.5 or $10 \%$ acrylamide) and transferred onto nitrocellulose membranes (Hybond TM-C Super; Amersham Biosciences Inc). The membranes were blocked in TBST $(0.2 \mathrm{~mol} / \mathrm{l} \mathrm{NaCl}$, $10 \mathrm{mmol} / \mathrm{l}$ Tris (pH 7.4), $0.2 \%$ Tween-20) containing 5\% nonfat dry milk for $1 \mathrm{~h}$, then incubated with mouse monoclonal antibodies against phosphorylated MAPK3/1 (Cell Signaling Technology, Danvers, MA, USA), cyclin D1 (Progen, Heidelberg, Germany), IGF1 receptor (Oncogene Research Product), ESR1, cyclin E, $\beta$-actin (Santa Cruz, St Louis, MO, USA), or rabbit polyclonal antibodies against MAPK3/1 (Cell Signaling Technology) in TBST containing 5\% nonfat dry milk overnight at $4{ }^{\circ} \mathrm{C}$. The membranes were then incubated with peroxidase-conjugated anti-mouse or anti-rabbit IgG (Amersham Biosciences Inc.) in TBST containing $2 \%$ nonfat dry milk. Bound antibodies were detected with an enhanced chemiluminescence system (Amersham Biosciences Inc). Each experiment was repeated thrice. The density of the bands on the gel was quantified by densitometric analysis using a Quantity One Scan System (ATTO, Tokyo, Japan). The mean values of absorbance relative to $\beta$-actin were indicated in Figs $1 \mathrm{c}, 2 \mathrm{~b}$ and $\mathrm{c}$.

\section{Total RNA extraction}

Total RNA was extracted by the acid guanidiniumphenol-chloroform method as described previously (Shiozawa et al. 2004). One microgram total RNA was treated with $1 \mathrm{U} / 10 \mu \mathrm{l}$ DNase I (Life Technologies).

\section{RT-PCR}

Estrogen- or IGF1-induced mRNA expression of cyclin D1, cyclin E, and IGF1 was evaluated using a 


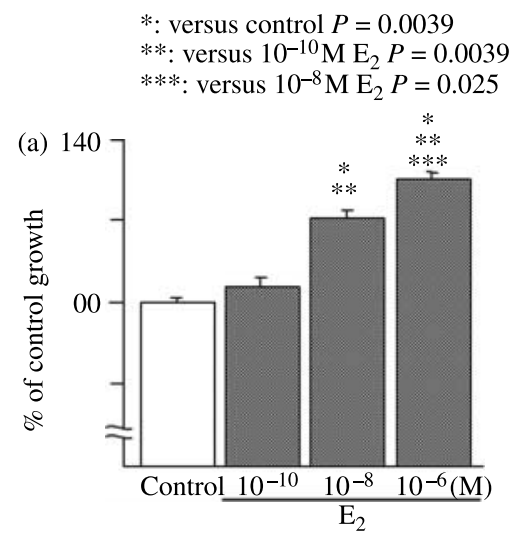

(b)

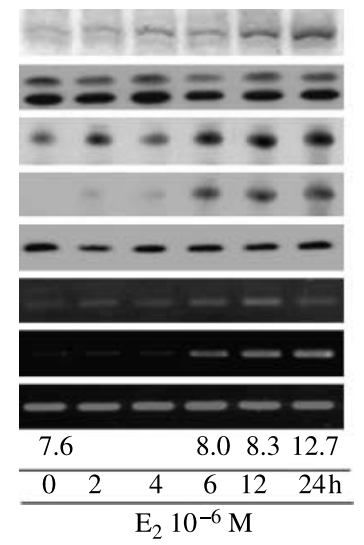

pMAPK3/1 (protein)

MAPK3/1 (protein)

Cyclin D1 (protein)

Cyclin E (protein)

$\beta$-Actin (protein)

Cyclin D1 (mRNA)

Cyclin E (mRNA)

GAPDH (mRNA)

S-phase fraction (\%)

(c)
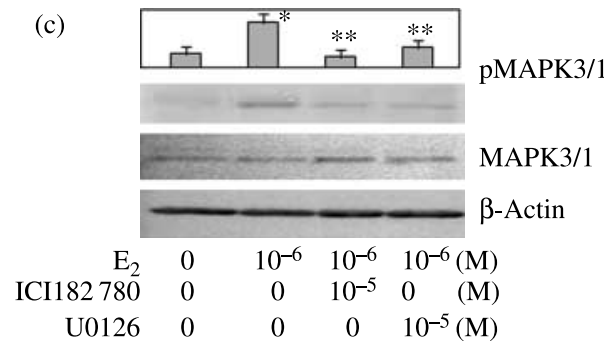

Figure 1 Estrogen-dependent proliferation, MAPK3/1 activation, and cyclin expression in Ishikawa cells. (a) Ishikawa cells were serum starved for $48 \mathrm{~h}$ as described in Experimental procedures, and $\mathrm{E}_{2}$ was added. Twenty-four hours after $\mathrm{E}_{2}$ addition, viable cells were measured using a WST-1 assay. $E_{2}$ treatment increased the proliferation of Ishikawa cells in a dose-dependent manner with significant differences. (b) $E_{2}$ was added to Ishikawa cells after serum starvation and the expression of cyclins and MAPK3/1 was examined using western blotting and RT-PCR. The S-phase fraction was examined using flow cytometry. $E_{2}\left(10^{-6} \mathrm{M}\right)$ treatment increased the S-phase fraction, and induced the up-regulation of cyclin D1, which was followed by the expression of cyclin E and MAPK3/1 activation. (c) Effect of an ER antagonist (ICI 182780 ) and an MAP2K inhibitor (U0126) on the activation of MAPK3/1. Ishikawa cells were treated with ICI $182780\left(10^{-5} \mathrm{M}\right)$ or $\mathrm{U} 0126\left(10^{-5} \mathrm{M}\right)$ for $6 \mathrm{~h}$ after $\mathrm{E}_{2}$ treatment, and MAPK3/1 phosphorylation was evaluated using western blotting. Treatment with ICI 182780 or U0126 suppressed the expression of pMAPK with significant differences. *Versus control, $P<0.05$, ${ }^{\star *}$ versus $\mathrm{E}_{2}$ alone, $P<0.05$. (a)

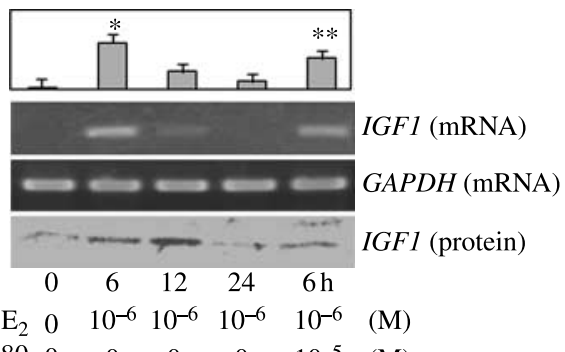

$\begin{array}{lllllll}\text { ICI182 } 780 & 0 & 0 & 0 & 0 & 10^{-5} & \text { (M) }\end{array}$

(b)

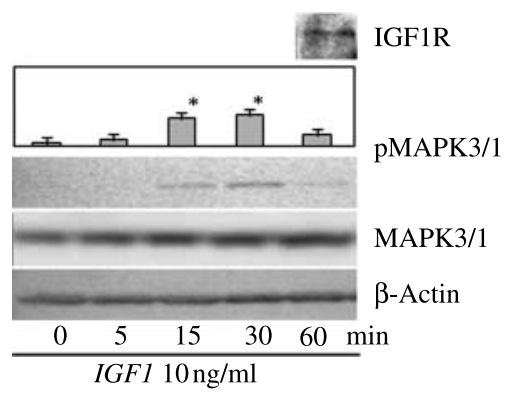

(c)

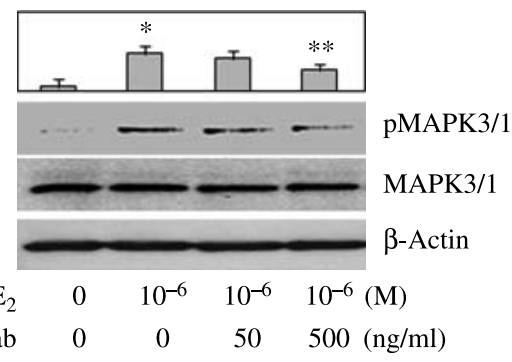

Anti-IGF1R ab $\quad 0 \quad 0 \quad 50 \quad 500(\mathrm{ng} / \mathrm{ml})$

Figure 2 Estrogen-induced expression and secretion of IGF1, and IGF1-induced MAPK3/1 activation in Ishikawa cells. (a) $E_{2}$ treatment significantly induced the expression of IGF1 mRNA with a peak at $6 \mathrm{~h}$ after treatment. Immunoprecipitation using the conditioned medium of $E_{2}$-treated Ishikawa cells indicated the secretion of IGF1 protein, which peaked $12 \mathrm{~h}$ after $\mathrm{E}_{2}$ addition. These reactions were suppressed ICI 182780 by $36 \%$ for IGF1 mRNA $(P<0.05)$ and by $49 \%$ for IGF1 protein. *Versus control, $P<0.05$, ** versus $\mathrm{E}_{2}$ alone, $P<0.05$ (b) Recombinant IGF1 $(10 \mathrm{ng} / \mathrm{ml})$ significantly induced the MAPK3/1 activation of Ishikawa cells from 15 to 30 min after the addition. *Versus control, $P<0.05$ (c) $E_{2}$-induced MAPK3/1 activation was suppressed by anti-IGF1 receptor antibody dose dependently $(17 \%$ reduction for $50 \mathrm{ng} / \mathrm{ml}, 57 \%$ reduction for $500 \mathrm{ng} / \mathrm{ml}$, $P<0.05) 6 \mathrm{~h}$ after $\mathrm{E}_{2}$ stimulation. *Versus control, $P<0.05$, ${ }^{* *}$ versus $\mathrm{E}_{2}$ alone, $P<0.05$.

semiquantitative reverse transcription-PCR (RT-PCR) assay. RT was performed using an RNA PCR Kit (Takara Shuzo, Otsu, Japan), with a $1 \mu \mathrm{g}$ RNA sample being added to $20 \mu \mathrm{l}$ of a reaction mixture consisting of $10 \mathrm{mmol} / \mathrm{l} \mathrm{Tris}-\mathrm{HCl}$ (pH 8.3), $50 \mathrm{mmol} / \mathrm{l} \mathrm{KCl}, 5 \mathrm{mmol} / \mathrm{l}$ $\mathrm{MgCl}_{2}, 1 \mathrm{mmol} / \mathrm{l} \mathrm{dNTP}$ mixture, $1 \mathrm{U} / \mu \mathrm{l}$ Rase inhibitor, $0.25 \mathrm{U} / \mu \mathrm{l}$ avian myeloblastosis virus-derived reverse transcriptase, and $0.125 \mu \mathrm{mol} / 1$ oligo $\mathrm{d}(\mathrm{T})$-adaptor primer. Using a thermal cycler (Gene Amp PCR System 
2400-R; Perkin-Elmer, Norwalk, CT, USA), the reaction mixture was incubated at $42{ }^{\circ} \mathrm{C}$ for $30 \mathrm{~min}$, heated to $99{ }^{\circ} \mathrm{C}$ for $5 \mathrm{~min}$, and then cooled down to $5{ }^{\circ} \mathrm{C}$ for $5 \mathrm{~min}$. One microliter of the RT products, containing $50 \mathrm{ng}$ reverse-transcribed total RNA, was amplified by adding $20 \mu \mathrm{l}$ of a PCR mixture containing $10 \mathrm{mmol} / \mathrm{l}$ Tris-HCl (pH 8.3), $50 \mathrm{mmol} / 1 \mathrm{KCl}, 2.5 \mathrm{U} / 100 \mu \mathrm{l}$ TaKaRa Taq DNA polymerase, with $0.2 \mu \mathrm{mol} / \mathrm{l}$ of a set of 21 - to 24-mer oligonucleotide primers for cyclin D1, cyclin E, IGF1, or glyceraldehyde-3-phosphate dehydrogenase (GAPDH) cDNA. Primers were synthesized to encompass a specific segment of the cDNA sequence of cyclin D1 (Kaneuchi et al. 2003; sense, 5'-TCTAAGATGAAGGAGACCATC ${ }^{\prime}$ and antisense, 5'-GCGGTAGTAGGACAGGAAGTTGTT-3'), cyclin E (Takano et al. 2000; sense, 5'-ATGGTATACTTGCTGCTTCGGCC- $3^{\prime}$ and antisense, $5^{\prime}$-AGAACGTGGAGCAGGCGCGCAACT-3'), IGF1 (Hana \& Murphy 1994; sense, 5'-CACTGTCACTGCTAAATTCA-3' and antisense, 5'-CTGTGGGCTTGTTGAAATAA-3', or GAPDH (sense, $5^{\prime}$-ACGACCACTTTGTCAAGCTC- $3^{\prime}$ and antisense $5^{\prime}$-GGTCTACATGGCAACTGTGA-3'). The corresponding cDNA fragments were denatured at $94{ }^{\circ} \mathrm{C}$ for $30 \mathrm{~s}$, annealed at $55^{\circ} \mathrm{C}$ for $1 \mathrm{~min}$, and extended at $72{ }^{\circ} \mathrm{C}$ for $1 \mathrm{~min}$. After 30 cycles of amplification, the PCR products were analyzed on a $2 \%$ agarose gel, and the bands were visualized using ethidium bromide by exposure on a u.v. transilluminator. Each experiment was performed thrice independently. Densitometric analysis was performed using a Quantity One Scan System (ATTO). Gene expression was represented by the relative yield of $\mathrm{PCR}$ product from the target sequence to that from the $G A P D H$ gene, because the stable expression of the GAPDH gene under various conditions has been reported (Gorzelniak et al. 2001, Silver et al. 2006, Murthi et al. 2008). The mean values of results were indicated in Figs 2a and 3c.

\section{Cell cycle analysis}

The cell cycle was analyzed in $E_{2}$-treated Ishikawa cells, using a cycleTEST (Becton Dickinson, Franklin Lakes, NJ, USA) and FACScan flow cytometry (Becton Dickinson).

\section{Immunoprecipitation}

Because the concentration of secreted IGF1 protein in the culture medium was low to detect using western blotting, IGF1 protein secreted into the medium of $\mathrm{E}_{2}$-stimulated Ishikawa cells was examined by immunoprecipitation using a Protein A Immunoprecipitation Kit (Kirkegaard \& Perry Laboratories, Gaithersburg, MD, USA). The conditioned medium was collected from Ishikawa cells

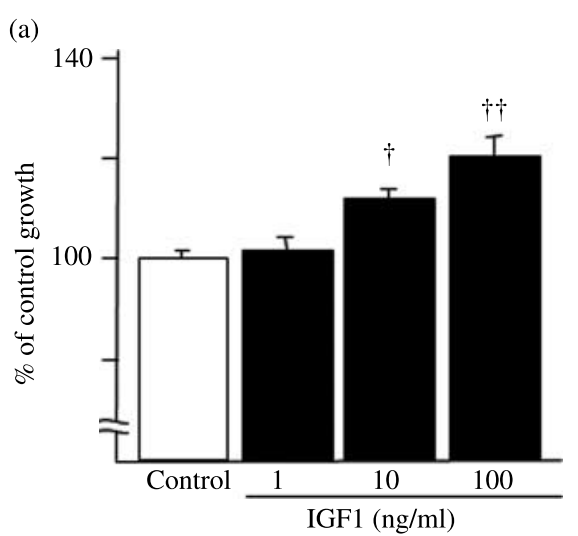

(b)

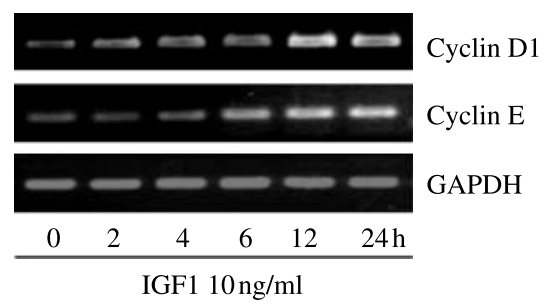

(c)

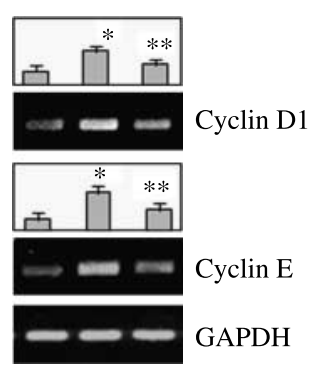

$\begin{array}{llllll}\text { IFG-1 } & 0 & 10 & 10 & (\mathrm{ng} / \mathrm{ml})\end{array}$

$\begin{array}{lllll}\mathrm{U} 0126 & 0 & 0 & 10^{-5} & \text { (M) }\end{array}$

Figure 3 IGF-induced proliferation and up-regulation of cyclin in Ishikawa cells. (a) After serum starvation of Ishikawa cells for $48 \mathrm{~h}$, recombinant IGF was added and the viable cells were counted using a WST-1 assay. IGF1 stimulated the proliferation of Ishikawa cells in a dose-dependent manner with significant differences. ${ }^{\dagger}$ Versus control $P<0.05,{ }^{\dagger+}$ versus IGF-I $10 \mathrm{ng} / \mathrm{ml} P<0.05$. (b) IGF1 induced a stepwise up-regulation of cyclin D1 mRNA with a peak $12 \mathrm{~h}$ after the addition, followed by that of cyclin E mRNA. (c) The IGF1-induced up-regulation of cyclin D1 and $\mathrm{E} 12 \mathrm{~h}$ after addition was significantly suppressed by $\mathrm{U} 0126$ by $37 \%$ and $42 \%$ respectively. ${ }^{*}$ Versus control, $P<0.05$, ** versus $\mathrm{E}_{2}$ alone, $P<0.05$.

treated with $10^{-6} \mathrm{M} \mathrm{E}_{2}$ at 6,12 , and $24 \mathrm{~h}$ after $\mathrm{E}_{2}$ addition, or from those cells treated with $10^{-5} \mathrm{M} \mathrm{ICI}$ 182 780. After preclear, $1 \mathrm{ml}$ of the conditioned medium was incubated with anti-IGF1 antibody (BioCarta, San Diego, CA, USA) overnight at $4{ }^{\circ} \mathrm{C}$ and IGF1 precipitates were collected for $1 \mathrm{~h}$ on protein-A agarose beads. After washing with lysis buffer thrice, precipitates were resuspended in a Laemmli SDS sample buffer and resolved by SDS-PAGE (15\% acrylamide). The resolved 
immunoprecipitates were electrotransferred onto a nitrocellulose membrane and detected by immunoblotting using an antibody against IGF1.

\section{WST-1 assay}

Ishikawa cells were cultured in 96-well plates, with various concentration of $E_{2}$. Cell proliferation was evaluated with Cell Proliferation Reagent WST-1 (Roche) according to the manufacturer's protocol. Each experiment was repeated thrice.

\section{Immunostaining of MAPK3/1 and phosphorylated MAPK3/1}

\section{Histological materials}

Thirty normal endometrial tissue specimens (proliferative phase: 9 cases; secretory phase: 21 cases), and 48 endometrial carcinoma specimens (grade 1, 27 cases; grade 2, 11 cases; grade 3,10 cases) were subjected to the study. These tissues were used with the approval of the Ethics Committee at Shinshu University School of Medicine after obtaining written consent from the patients.

\section{Staining procedures}

Immunohistochemical staining was performed on formalin-fixed, paraffin-embedded tissue sections by the streptavidin-biotin-peroxidase complex method using a Histofine SAB-PO kit (Nichirei, Tokyo, Japan). The primary antibodies, MAPK3/1 Antibody and Phospho-MAPK3/1 (Thr202/Tyr204; E10) Monoclonal Antibody (Cell Signaling Technology), were used at a dilution of 1:100. The following procedure was described previously (Shih et al. 2003).

\section{Interpretation of immunohistochemical staining}

Positive staining was identified by brown-colored products in the nucleus or in the cytoplasm. All the control slides yielded negative staining. Nuclear staining in each section was evaluated by the percentage of stained cells in 500 arbitrarily selected cells and described as 'positivity index (PI)' (maximum score: 100). The PI for cytoplasmic staining was calculated by multiplying the intensity of cytoplasmic staining (strongly positive $(=2)$, weakly positive $(=1)$ ) with the matched percentage of nuclear-positive cells among 500 cells (maximum score: 200 ).

\section{Statistical analysis}

Statistical analysis was performed by the Mann-Whitney test (Statview System, Macintosh). Differences were considered significant when $P<0.05$.

\section{Result}

\section{$E_{2}$ stimulates the proliferation of Ishikawa cells in a dose-dependent manner}

To evaluate the effect of $E_{2}$ on the proliferation of endometrial carcinoma Ishikawa cells, $\mathrm{E}_{2}$ was added after incubation in serum-starved conditions for $48 \mathrm{~h}$, and viable cells were measured using a WST-1 assay $24 \mathrm{~h}$ after $E_{2}$ addition. The result indicated that the $E_{2}$ treatment at a concentration of $10^{-8} \mathrm{M}$ and $10^{-6} \mathrm{M}$ increased the cell proliferation compare with the control by $20 \%$ and $28 \%$ respectively $(P<0.05$; Fig. 1a). Cell cycle analysis showed that the $S$-phase fraction of $E_{2^{-}}$ untreated and $\mathrm{E}_{2}$-treated cells after $24 \mathrm{~h}$ was $7.6 \%$ and $12.7 \%$ respectively (Fig. 1b). Western blot analysis demonstrated that a weak, baseline expression of cyclin D1 was observed before the addition of $\mathrm{E}_{2}$, and the expression of cyclin D1 protein was then elevated $\sim 6 \mathrm{~h}$ after $\mathrm{E}_{2}$ treatment. RT-PCR revealed that mRNA expression of cyclin D1 increased $6 \mathrm{~h}$ after $\mathrm{E}_{2}$ stimulation, with a peak at $12 \mathrm{~h}$ after $\mathrm{E}_{2}$ treatment. The expression of cyclin $\mathrm{E}$ protein and mRNA appeared $6 \mathrm{~h}$ after $\mathrm{E}_{2}$ stimulation and then increased thereafter (Fig. 1b). These findings indicate that $\mathrm{E}_{2}$ stimulates cell cycle progression with transcriptional activation of cyclin D1 and E.

\section{$E_{2}$-induced activation of MAPK3/1 in Ishikawa cells}

To investigate the involvement of the MAPK $3 / 1$ pathway in $E_{2}$-induced proliferation of Ishikawa cells, we examined the activation of this pathway by western blotting using a specific antibody against activated (phosphorylated) MAPK3/1 (pMAPK3/1). $\mathrm{E}_{2}$ treatment induced the activation of MAPK $3 / 12 \mathrm{~h}$ after stimulation, which reached a peak $24 \mathrm{~h}$ after stimulation. The expression of nonactive MAPK3/1 remained unchanged throughout the experiment (Fig. 1b). When Ishikawa cells were treated with ER antagonist (ICI 182780 ) or an MAP2K inhibitor (U0126), the $\mathrm{E}_{2}$-induced MAPK3/1 phosphorylation $6 \mathrm{~h}$ after the addition of $\mathrm{E}_{2}$ was significantly reduced by $78 \%(P<0.05)$ and $56 \%$ $(P<0.05)$ respectively (Fig. 1c). These findings suggest that $E_{2}$-induced activation of the MAPK pathway is involved in $\mathrm{E}_{2}$-induced proliferation of Ishikawa cells.

\section{$E_{2}$-induced MAPK3/1 activation is mediated through IGF1 synthesis and secretion}

Because the activation of the MAPK pathway has been thought to be evoked by growth factors via their receptors, we performed a preliminary screening of several growth factors including IGF, EGF, and TGFA to examine whether the expression of these growth 
factors could be induced by estrogen in Ishikawa cells. Consequently, we identified IGF1 to exhibit the most marked estrogen dependency in terms of the degree of estrogen-induced up-regulation and ER antagonistinduced down-regulation. Therefore, we focused on the involvement of IGF1 in estrogen-dependent growth of endometrial carcinoma cells. RT-PCR revealed that $\mathrm{E}_{2}$-induced IGF1 mRNA expression peaked $6 \mathrm{~h}$ after $\mathrm{E}_{2}$ addition and then disappeared at $24 \mathrm{~h}$, and ICI 182780 pretreatment significantly decreased the $\mathrm{E}_{2}$-induced IGF1 mRNA expression by $36 \%$ (Fig. 2a). To identify the engagement of IGF1 in the $\mathrm{E}_{2}$-induced growth mechanism, the secretion of IGF1 into the culture medium in $\mathrm{E}_{2}$-treated Ishikawa cells was then examined. The conditioned medium after $\mathrm{E}_{2}$ with/without ICI 182780 treatment was collected and immunoprecipitated with anti-IGF1 antibodies. The following immunoblotting revealed that the IGF1 protein in the conditioned medium peaked $12 \mathrm{~h}$ after $\mathrm{E}_{2}$ treatment, and ICI 182780 treatment reduced the $\mathrm{E}_{2}$-induced IGF1 secretion $6 \mathrm{~h}$ after addition by $49 \%$ (Fig. 2a). These findings indicate that $\mathrm{E}_{2}$ induces IGF1 synthesis and secretion into the culture medium in Ishikawa cells, suggesting a possible presence of an IGF1-mediated autocrine mechanism.

The role of IGF1 in $E_{2}$-induced MAPK3/1 activation was then investigated. Western blotting confirmed that Ishikawa cells expressed IGF1 receptors (Fig. 2b), and recombinant IGF1 induced a rapid and transient MAPK3/1 phosphorylation that began $15 \mathrm{~min}$ after IGF1 addition with significant differences $(P<0.05)$, and disappeared by $1 \mathrm{~h}$ (Fig. 2b). To further confirm the contribution of IGF1 in $\mathrm{E}_{2}$-induced MAPK3/1 activation, we examined the effect of anti-IGF1 receptor neutralization antibody. When cells were treated with anti-IGF1 receptor antibody, a partial inhibition of $\mathrm{E}_{2}$-induced MAPK3/1 activation (anti-IGF1 receptor antibody: $50 \mathrm{ng} / \mathrm{ml}, 17 \%$ reduction; $500 \mathrm{ng} / \mathrm{ml}, 57 \%$ reduction, $P<0.05)$ was observed $6 \mathrm{~h}$ after the addition of $\mathrm{E}_{2}$ (Fig. 2c). These results indicated that the $E_{2}$-induced MAPK3/1 activation was mediated by an autocrine stimulation of IGF1 in Ishikawa cells.

\section{IGF1 stimulates the proliferation of Ishikawa cells in a dose-dependent manner}

Since $\mathrm{E}_{2}$ treatment activated the MAPK3/1 pathway via an autocrine system of IGF1, we examined whether IGF1 can enhance the proliferation of Ishikawa cells. A WST-1 assay revealed that the addition of recombinant IGF1 at concentrations of $10 \mathrm{ng} / \mathrm{ml}$ and $100 \mathrm{ng} / \mathrm{ml}$ for $24 \mathrm{~h}$ increased cell proliferation compared with the control by $19 \%$ and $32 \%$ respectively, $(P<0.05$; Fig. $3 a)$.

\section{IGF1 induces cyclin D1 and E via activation of the MAPK3/1 pathway}

To investigate the molecular mechanism of IGF1induced cell proliferation, we examined the mRNA expression of cyclin D1 and E after IGF1 treatment. RT-PCR revealed that mRNA expression of cyclin D1 increased $2 \mathrm{~h}$ after IGF1 stimulation, with a peak at $12 \mathrm{~h}$ after $\mathrm{E}_{2}$ treatment. The expression of cyclin E mRNA increased from $4 \mathrm{~h}$ after IGF1 stimulation (Fig. 3b). To investigate whether the activation of MAPK3/1 was involved in the IGF1-induced expression of cyclin D1 and E, we examined the effect of U0126. RT-PCR revealed that treatment with U0126 significantly reduced the IGF1-induced cyclin D1 and E expression $12 \mathrm{~h}$ after the addition of IGF1 by $37 \%$ for cyclin D1 $(P<0.05)$ and by $42 \%$ for cyclin $\mathrm{E}(P<0.05$, Fig. $3 \mathrm{c})$. These findings suggest that IGF1 induced cyclin D1 and $E$ via activation of the MAPK3/1 pathway.

\section{$E_{2}$-induced cell proliferation is dependent on the MAPK3/1 pathway via an autocrine mechanism of IGF1}

MAPK3/1 dependency in $E_{2^{-}}$or IGF1-induced cell proliferation was examined using an MAP2K inhibitor and an antibody against the IGF1 receptor in Ishikawa cells. $E_{2}$ treatment for $24 \mathrm{~h}$ enhanced the proliferation of Ishikawa cells by $20 \%$ (lane 2, Fig. 4) compared with the control with a significant difference $(P=0.011)$, and the

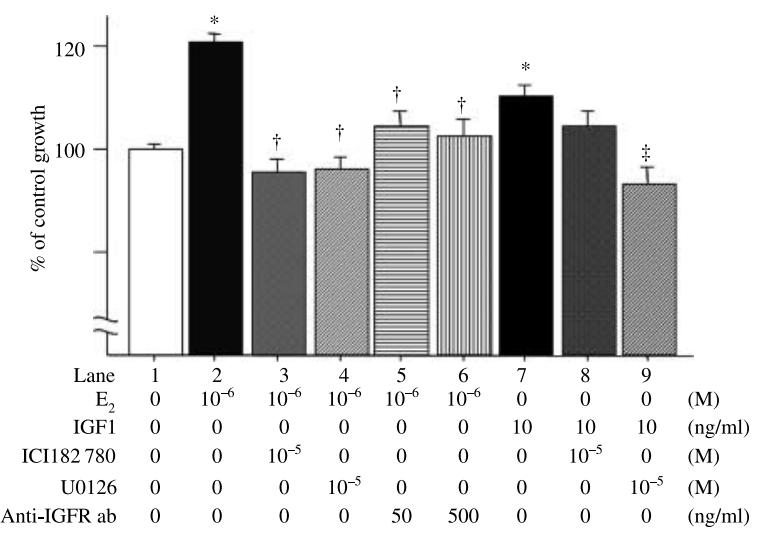

Figure 4 Effect of ICI 182780 , U0126, and anti-IGF1 receptor antibody on $\mathrm{E}_{2}$ - or IGF1-induced proliferation of Ishikawa cells. Ishikawa cells were serum starved for $48 \mathrm{~h}$, and $\mathrm{E}_{2}\left(10^{-6} \mathrm{M}\right)$ or IGF1 $(10 \mathrm{ng} / \mathrm{ml})$ was added. Viable cells were measured $24 \mathrm{~h}$ after the addition using a WST-1 assay. ICl 182780 suppressed the $E_{2}$-induced proliferation of Ishikawa cells (lane 3) with a significant difference, but not IGF1-induced proliferation (lane 8 ). U0126 suppressed both $\mathrm{E}_{2^{-}}$(lane 4) and IGF1 (lane 9)-induced proliferation. Anti-IGF1 receptor antibody suppressed $\mathrm{E}_{2}$-induced proliferation (lanes 5,6 ). *versus control $P<0.05$, ${ }^{\dagger}$ versus $\mathrm{E}_{2}$ alone $P<0.05$, ${ }^{\ddagger}$ versus IGF1 alone $P<0.05$. 
$\mathrm{E}_{2}$-induced proliferation was blocked by the use of ICI 182780 (lane 3) or U0126 (lane 4). Anti-IGF1 receptor antibody also inhibited the $\mathrm{E}_{2}$-induced cell proliferation (lanes 5 and 6). IGF1 treatment increased the proliferation of Ishikawa cells by $10 \%$ compared with the control after $24 \mathrm{~h}(P=0.039$; lane 7). Treatment with ICI 182780 slightly decreased the IGF1-induced cell proliferation, but the difference was not significant (lane 8). U0126 inhibited the effect of IGF1 on cell proliferation (lane 9). Collectively, these findings suggest that $\mathrm{E}_{2}$-stimulated proliferation of Ishikawa cells is mediated by MAPK3/1 activation via autocrine stimulation by IGF1.

\section{Immunostaining for MAPK3/1 and phosphorylated MAPK3/1 in normal endometrium and endometrial carcinoma}

To investigate the involvement of MAPK3/1 in the growth of endometrial tissues, the immunohistochemical expression of MAPK3/1 and its activation (phosphorylation) were examined in normal and malignant endometrial tissues. The immunoreactivity for MAPK3/1 and phosphorylated (p)MAPK3/1 was observed both in the cytoplasm and nucleus. In normal endometrial glandular cells, the expression of cytoplasmic MAPK3/1 was observed both in the proliferative and secretory phases, whereas that of pMAPK3/1 was
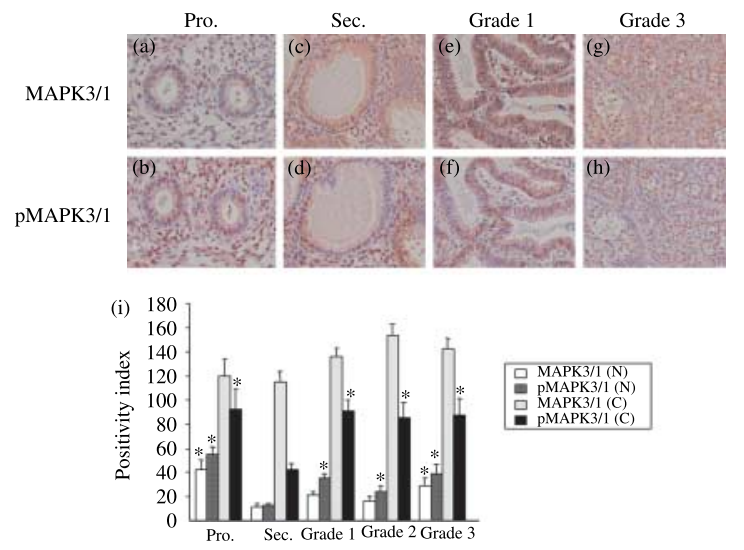

Figure 5 Immunohistochemical detection of MAPK3/1 and phosphorylated (p)MAPK in endometrial tissues. The expression of MAPK (a, c, e and g) and pMAPK (b, d, f and $h)$ in normal endometrium ( $(a-d)$ and endometrial carcinoma $(e-h)$. (a) and (b), (c) and (d), (e) and (f), and (g) and (h) are serial sections. (i) Shows a graphical representation of the results. The expression of pMAPK both in the cytoplasm and nucleus was increased in the normal proliferative phase endometrium and endometrial carcinoma compared with that in the secretory phase endometria $(P<0.05)$. There was no significant difference in the expression of pMAPK between different histological grades of endometrial carcinoma. The expression of cytoplasmic MAPK did not show marked changes between histological groups. Pro. proliferative phase; Sec., secretory phase. *Significantly different from that of the normal secretory phase endometrium $(P<0.05)$. more abundant in the proliferative phase than the secretory phase $(P<0.0001$ in the nucleus, $P=0.0018$ in the cytoplasm; Fig. 5). The expression of MAPK3/1 increased in all cases of endometrial carcinoma examined, and that of pMAPK $3 / 1$ increased significantly compared with that in the secretory phase endometrium (versus grade 1: $P<0.0001$ in the nucleus, $P=0.0001$ in the cytoplasm; versus grade 2: $P=0.04$ in the nucleus, $P=0.0084$ in the cytoplasm; versus grade 3 : $P=0.003$ in the nucleus, $P=0.0019$ in the cytoplasm; Fig. 5). However, there was no significant relationship among the pathological grades of endometrial carcinoma. These findings indicated that the expression of pMAPK3/1 increased in actively proliferating tissues such as normal proliferative phase endometrium and endometrial carcinoma.

\section{Discussion}

The present study demonstrated that $\mathrm{E}_{2}$ induced the up-regulation of IGF1 expression and significantly enhanced the cell proliferation of endometrial carcinoma Ishikawa cells. In addition, we have also shown that 1) $\mathrm{E}_{2}$ induced the production and secretion of IGF1, 2) Ishikawa cells expressed IGF1 receptors, 3) treatment with recombinant IGF1 stimulated the proliferation of Ishikawa cells, and 4) treatment with anti-IGF1 receptor neutralization antibody effectively inhibited both $\mathrm{E}_{2}$ - and IGF1-induced growth of Ishikawa cells. These findings clearly demonstrated the presence of an autocrine loop of IGF1 in estrogen-induced cell proliferation of Ishikawa cells. Previous studies using primary cultures of endometrial carcinoma cells (Reynolds et al. 1996) and endometrial carcinoma cell lines (Takeda et al. 1996, Reynolds et al. 1998) suggested the possible existence of IGF1- or TGFA-mediated autocrine loops; however, the involvement of estrogen stimulation in the autocrine system was not reported. Although Hana \& Murphy (1994) reported an increase in IGFI mRNA expression after estrogen treatment, the secretion of IGF1 protein was not examined. In breast carcinoma MCF-7 cells, an estrogen-related autocrine loop has been reported to stimulate cell proliferation via ERBB2 and its ligand, heregulin (Keshamouni et al. 2002). Therefore, to our knowledge, this is the first report showing the presence of an $\mathrm{E}_{2}$-induced entire autocrine loop mediated by IGF1 in the cell proliferation of endometrial carcinoma cells. The $\mathrm{E}_{2}$ concentration used in the present study $\left(10^{-6} \mathrm{M}\right)$ is higher than that of physiological condition; however, elevated $\mathrm{E}_{2}$ concentrations in the tumor microenvironment several times higher than that of the physiological levels have been reported (Ito et al. 2007). IGF1-induced cell proliferation was half of that of $\mathrm{E}_{2}$-induced in this 
study, suggesting that the presence of other $\mathrm{E}_{2}$-induced growth mechanisms than IGF1 cannot fully be denied.

The molecular mechanism of $\mathrm{E}_{2}$-induced transcription of IGF1 is largely unknown. In the present study, we observed an increase in the expression of $I G F 1$ mRNA $6 \mathrm{~h}$ after $\mathrm{E}_{2}$ treatment, and this may be consistent with that observed in $\mathrm{E}_{2}$-administered rat uterus (Murphy \& Ghahary 1990). More recently, the expression of IGF1 has reportedly been induced by cyclic AMP-dependent kinase via activation of HS3D located in the IGF1 gene promoter and a transcription factor, CCAAT/enhancer-binding protein $\delta$ in rat osteoblasts (Billiard et al. 2001). Kleinman et al. (1995) reported that $E_{2}$ sensitized the effects of IGF1 by elevating receptor levels and also decreasing the expression of IGF-binding protein-3, which potentially has an inhibitory function for IGF1. Thus, further studies are needed to clarify the molecular link between estrogen stimulation and up-regulation of IGF1.

Our study also showed that the classical MAPK pathway, MAPK3/1, is involved in estrogen-induced cell proliferation via the IGF1 autocrine loop in endometrial carcinoma Ishikawa cells. Treatment with recombinant IGF1 also induced MAPK3/1 phosphorylation and cell proliferation of Ishikawa cells, which were suppressed by an MAP2K inhibitor, U0126. The activation of MAPK3/1 peaked from 15 to 30 min after the IGF1 stimulation. Earlier studies using fibroblasts indicated that RAS-MAP2K-MAPK3/1 activation is important in IGF1-related cell proliferation (Lu \& Campisi 1992, Jhun et al. 1994, Sasaoka et al. 1996). In experiments using gynecological cancer cell lines, such as a cervical carcinoma cell line ( $\mathrm{SiHa})$ and an ovarian carcinoma cell line (OVCR3), IGF1 was reported to transmit the signal possibly via the MAPK3/1 pathway (Shen et al. 2004). However, in breast carcinoma MCF-7 cells, the mitogenic signal of IGF1 did not pass through the MAPK3/1 pathway but through the phosphatidylinositol 3-kinase pathway (Dufourny et al. 1997). In endometrial carcinoma cells, the putative growth factors relaying the signals to the MAPK3/1 pathway reported to date were EGF (Tang et al. 2006), keratinocyte growth factor, and fibroblast growth factor-10 (Taniguchi et al. 2003). Accordingly, we provide the first report of a signal transduction pathway between $\mathrm{E}_{2}$ stimulation, subsequent IGF1 stimulation, MAPK3/1 activation, and cyclins up-regulation, which leads to the cell proliferation of endometrial carcinoma cells.

The current study demonstrated the time course between $\mathrm{E}_{2}$ stimulation, IGF1 stimulation, MAPK3/1 activation, and up-regulation of cyclin D1 and cyclin E in Ishikawa cells. $E_{2}$-induced expression of IGF1 was observed $6 \mathrm{~h}$ after $\mathrm{E}_{2}$ stimulation, and IGF1-induced MAPK3/1 activation was observed as early as $15 \mathrm{~min}$. The expression pattern of $\mathrm{E}_{2}$-induced cyclin D1 mRNA paralleled that of cyclin D1 protein. Since the significant elevation of cyclin D1 protein expression occurred $6 \mathrm{~h}$ after $\mathrm{E}_{2}$ stimulation, a signal transduction pathway from IGF1 and cyclin D1 via MAPK3/1 seems to be plausible. However, since a weak up-regulation of cyclin D1 mRNA was observed $2 \mathrm{~h}$ after $E_{2}$ stimulation, another immediate pathway between $\mathrm{E}_{2}$ stimulation and cyclin D1 might also be present, as we demonstrated previously in normal endometrial cells (Shiozawa et al. 2004). Although a weak baseline expression of cyclin $\mathrm{E}$ mRNA was observed until $4 \mathrm{~h}$ after $\mathrm{E}_{2}$ stimulation, the expression pattern of $\mathrm{E}_{2}$-induced cyclin $\mathrm{E}$ mRNA also correlated with that of cyclin $E$ protein. In our study, up-regulation of cyclin $\mathrm{E}$ was also observed $6 \mathrm{~h}$ after $\mathrm{E}_{2}$ stimulation. The molecular mechanism of cyclin $\mathrm{E}$ up-regulation remains undetermined; however, the cyclin E gene has multiple E2F1 binding sites, and E2F1 has been reported to activate the expression of cyclin (DeGregori et al. 1995, Ohtani et al. 1995). MAPK3/1-induced up-regulation of E2F1 has also been reported (Berkovich \& Ginsberg 2001, Pintus et al. 2003). Collectively, the link between MAPK3/1 activation and up-regulation of cyclin D1 and cyclin E may be mediated by various factors.

Finally, we have demonstrated immunohistochemically that the expression of pMAPK3/1 was increased in both normal proliferative phase endometrium and endometrial carcinoma. The increased expression of pMAPK3/1 in endometrial carcinoma observed in the present study was similar to a recent study (Mizumoto et al. 2007). This is not surprising, because the in vivo growth activity of normal endometrial glandular cells in the proliferative phase is as vigorous as that in endometrial carcinoma cells (Shiozawa et al. 1996, Shih et al. 2003). Thus, activation of the MAPK3/1 pathway seems to be functioning not only in endometrial carcinoma cells but also in normal endometrial glandular cells in vivo. Interestingly, the $\mathrm{E}_{2}$-induced MAPK3/1 activation, as observed in endometrial carcinoma Ishikawa cells, was not observed in cultured normal endometrial glandular cells in vitro (data not shown). Such a discrepancy may be due to the absence of endometrial stroma in the in vitro experiment culturing purified glandular cells (Shiozawa et al. 2001). Pierro et al. (2001) reported that normal endometrial stromal cells secrete IGF1 as a paracrine factor that stimulates the proliferation of neighboring glandular cells, indicating the presence of epithelial-stromal interactions via IGF1 in normal 
endometrium. This is consistent with the observation that the activity of cell proliferation of normal glandular cells in vitro is very low when cultured in the absence of stromal cells. All of these findings strongly suggest that endometrial carcinoma cells have acquired the capacity for cell growth independent of endometrial stroma, through having the autocrine loop of IGF1 stimulation.

In conclusion, our study demonstrated that activation of the MAPK3/1 pathway plays an important role in $\mathrm{E}_{2}$-induced growth of endometrial carcinoma cells, and its activation is mediated by IGF1 autocrine stimulation. This result suggests that IGF1 and its receptor can be a candidate for molecular targeting for endometrial carcinoma therapy.

\section{Declaration of interest}

We declare that there is no conflict of interest that could be perceived as prejudicing the impartiality of the research reported.

\section{Funding}

This work was supported in part by a Grant-in-aid for Scientific Research from the Ministry of Education, Science and Culture (No. 06454468 and No. 07807154), Japan.

\section{References}

Berkovich E \& Ginsberg D 2001 Ras induces elevation of E2F-1 mRNA levels. Journal of Biological Chemistry 276 42851-42856.

Billiard J, Grewal SS, Lukaesko L, Stork PJ \& Rotwein P 2001 Hormonal control of insulin-like growth factor I gene transcription in human osteoblasts: dual actions of cAMP-dependent protein kinase on CCAAT/enhancerbinding protein delta. Journal of Biological Chemistry 276 31238-31246.

DeGregori J, Kowalik T \& Nevins JR 1995 Cellular targets for activation by the E2F1 transcription factor include DNA synthesis- and G1/S-regulatory genes. Molecular and Cellular Biology 15 4215-4224.

Dufourny B, Alblas J, van Teeffelen HA, van Schaik FM, van der Burg B, Steenbergh PH \& Sussenbach JS 1997 Mitogenic signaling of insulin-like growth factor I in MCF-7 human breast cancer cells requires phosphatidylinositol 3-kinase and is independent of mitogen-activated protein kinase. Journal of Biological Chemistry 272 31163-31171.

Gorzelniak K, Janke J, Engeli S \& Sharma AM 2001 Validation of endogenous controls for gene expression studies in human adipocytes and preadipocytes. Hormone and Metabolic Research 33 625-627.
Granziani G, Tentori L, Portarena I, Vergani M \& Navarra P 2003 Valproic acid increases the stimulatory effects of estrogens on proliferation of human endometrial adenocarcinoma cells. Endocrinology 44 2822-2828.

Hana V \& Murphy LJ 1994 Expression of insulin-like growth factors and their binding proteins in the estrogen responsive Ishikawa human endometrial cancer cell line. Endocrinology 135 2511-2516.

Ito K, Utsunomiya H, Yaegashi N \& Sasano H 2007 Biological roles of estrogen and progesterone in human endometrial carcinoma - new developments in potential endocrine therapy for endometrial cancer. Endocrine Journal 54 667-679.

Jhun BH, Meinkoth JL, Leitner JW, Draznin B \& Olefsky JM 1994 Insulin and insulin-like growth factor-I signal transduction requires p21ras. Journal of Biological Chemistry 269 5699-5704.

Kaneuchi M, Sasaki M, Tanaka Y, Sakuragi N, Fujimoto S \& Dahiya R 2003 Quercetin regulates growth of Ishikawa cells through the suppression of EGF and cyclin D1. International Journal of Oncology 22 159-164.

Keshamouni VG, Mattingly RR \& Reddy KB 2002 Mechanism of 17-beta-estradiol-induced Erk1/2 activation in breast cancer cells. A role for HER2 AND PKC-delta. Journal of Biological Chemistry 277 22558-22565.

Kleinman D, Karas M, Roberts CT, LeRoith D, Phillip M, Segev Y, Levy J \& Sharoni Y 1995 Modulation of insulinlike growth factor 1 (IGF-1) receptors and membraneassociated IGF-binding proteins in endometrial cancer cells by edtradiol. Endocrinology 136 2531-2537.

Kolch W 2000 Meaningful relationships: the regulation of the Ras/Raf/MEK/ERK pathway by protein interactions. Biochemical Journal 351 289-305.

Li SF, Shiozawa T, Nakayama K, Nikaido T \& Fujii S 1996 Stepwise abnormality of sex steroid hormone receptors, tumor suppressor gene products (p53 and RB), and cyclin $\mathrm{E}$ in uterine endometrioid carcinoma. Cancer 77 321-328.

Lu K \& Campisi J 1992 Ras proteins are essential and selective for the action of insulin-like growth factor 1 late in the $\mathrm{G} 1$ phase of the cell cycle in BALB/c murine fibroblasts. PNAS 89 3889-3893.

Mizumoto Y, Kyo S, Mori N, Sakaguchi J, Ohno S, Maida Y, Hashimoto M, Takakura M \& Inoue M 2007 Activation of ERK1/2 occurs independently of KRAS or BRAF status in endometrial cancer and is associated with favorable prognosis. Cancer Science 98 652-658.

Murphy LJ 1994 Growth factors and steroid hormone action in endometrial cancer. Journal of Steroid Biochemistry and Molecular Biology 48 419-423.

Murphy LJ \& Ghahary A 1990 Uterine insulin-like growth factor-1: regulation of expression and its role in estrogeninduced uterine proliferation. Endocrine Reviews 11 443-453.

Murthi P, Fitzpatrick E, Borg AJ, Donath S, Brennecke SP \& Kalionis B 2008 GAPDH, 18S rRNA and YWHAZ are 
suitable endogenous reference genes for relative gene expression studies in placental tissues from human idiopathic fetal growth restriction. Placenta 29 798-801.

Nurse P 1997 Regulation of the eukaryotic cell cycle. European Journal of Cancer 33 1002-1004.

Ohtani K, DeGregori J \& Nevins JR 1995 Regulation of the cyclin E gene by transcription factor E2F1. PNAS 92 12146-12150.

Pages G, Lenormand P, L'Allemain G, Chambard JC, Meloche S \& Pouyssegur J 1993 Mitogen-activated protein kinases $\mathrm{p} 42 \mathrm{mapk}$ and $\mathrm{p} 44 \mathrm{mapk}$ are required for fibroblast proliferation. PNAS 90 8319-8323.

Peyssonnaux C \& Eychene A 2001 The Raf/MEK/ERK pathway: new concepts of activation. Biology of the Cell 93 53-62.

Pierro E, Minici F, Alesiani O, Miceli F, Proto C, Screpanti I, Mancuso S \& Lanzone A 2001 Stromal-epithelial interactions modulate estrogen responsiveness in normal human endometrium. Biology of Reproduction 64 831-838.

Pintus G, Tadolini B, Posadino AM, Sanna B, Debidda M, Carru C, Deiana L \& Ventura C 2003 PKC/Raf/ME$\mathrm{K} / \mathrm{ERK}$ signaling pathway modulates native-LDLinduced E2F-1 gene expression and endothelial cell proliferation. Cardiovascular Research 59 934-944.

Reynolds RK, Owens CA \& Roberts JA 1996 Cultured endometrial cancer cells exhibit autocrine growth factor stimulation that is not observed in cultured normal endometrial cells. Gynecologic Oncology 60 380-386.

Reynolds RK, Hu C \& Baker VV 1998 Transforming growth factor and insulin-like growth factor-1, but not epidermal growth factor, elict autocrine stimulation of mitogenesis in endometrial cancer cell lines. Gynecologic Oncology 70 202-209.

Sasaoka T, Ishiki M, Sawa T, Ishihara H, Takata Y, Imamura T, Usui I, Olefsky JM \& Kobayashi M 1996 Comparison of the insulin and insulin-like growth factor 1 mitogenic intracellular signaling pathways. Endocrinology 137 4427-4434.

Shen MR, Lin AC, Hsu YM, Chang TJ, Tang MJ, Alper SL, Ellory JC \& Chou CY 2004 Insulin-like growth factor 1 stimulates $\mathrm{KCl}$ cotransport, which is necessary for invasion and proliferation of cervical cancer and ovarian cancer cells. Journal of Biological Chemistry 279 40017-40025.

Sherr CJ 1995 Mammalian G1 cyclins and cell cycle progression. Proceedings of the Association of American Physicians 107 181-186.

Shih HC, Shiozawa T, Kato K, Imai T, Miyamoto T, Uchikawa J, Nikaido T \& Konishi I 2003 Immunohistochemical expression of cyclins, cyclin-dependent kinases, tumor suppressor gene products, Ki-67 and sex steroid receptors in endometrial carcinoma: positive staining for cyclin A as poor prognostic indicator. Human Pathology 34 471-478.

Shiozawa T, Li SF, Nakayama K, Nikaido T \& Fujii S 1996 Relationship between the expression of cyclins/cyclindependent kinases and sex steroid receptors/Ki67 in normal human endometrial glands and stroma during the menstrual cycle. Molecular Human Reproduction 2 745-752.

Shiozawa T, Horiuchi A, Kato K, Obinata M, Konishi I, Fujii S \& Nikaido T 2001 Up-regulation of p27Kip1 by progestins is involved in the growth suppression of the normal and malignant human endometrial glandular cells. Endocrinology 142 4182-4188.

Shiozawa T, Miyamoto T, Kashima H, Nakayama K, Nikaido T \& Konishi I 2004 Estrogen-induced proliferation of normal endometrial glandular cells is initiated by transcriptional activation of cyclin D1 via binding of c-Jun to an AP-1 sequence. Oncogene 23 8603-8610.

Silver N, Best S, Jiang J \& Thein SL 2006 Selection of housekeeping genes for gene expression studies in human reticulocytes using real-time PCR. BMC Molecular Biology 733.

Singleton DW, Feng Y, Burd CJ \& Khan SA 2003 Nongenomic activity and subsequent $\mathrm{c}$-fos induction by estrogen receptor ligands are not sufficient to promote deoxyribonucleic acid synthesis in human endometrial adenocarcinoma cells. Endocrinology 144 121-128.

Strauss J III \& Coutifaris C 1999 The endometrium and myometrium: regulation and dysfunction. In Reproductive Endocrinology, pp 218-256. Eds SSC Yen, RB Jaffe \& R Barbieri., 4 Philadelphia: WB Saunders Co..

Takano Y, Kato Y, van Diest PJ, Masuda M, Mitomi H \& Okayasu I 2000 Cyclin D2 overexpression and lack of p27 correlate positively and cyclin E inversely with a poor prognosis in gastric cancer cases. American Journal of Pathology 156 585-594.

Takeda S, Soutter WP, Dibb NJ \& White JO 1996 Biological activity of the receptor for macrophage colony-stimulating factor in the human endometrial cancer cell line, Ishikawa. British Journal of Cancer 73 615-619.

Tang LL, Yokoyama Y, Wan X, Iwagaki S, Niwa K \& Tamaya T 2006 PTEN sensitizes epidermal growth factor-mediated proliferation in endometrial carcinoma cells. Oncology Reports 15 855-859.

Taniguchi F, Harada T, Sakamoto Y, Yamauchi N, Yoshida S, Iwabe T \& Terakawa N 2003 Activation of mitogenactivated protein kinase pathway by keratinocyte growth factor or fibroblast growth factor-10 promotes cell proliferation in human endometrial carcinoma cells. Journal of Clinical Endocrinology and Metabolism $\mathbf{8 8}$ 773-780. 